\title{
“Cautela, seguir mudo”. Madrid’s Diplomatic Response to the Emergence of the Irish Free State 1918-1931
}

\author{
Alvaro Jaspe \\ University of Ulster
}

Copyright (c) 2008 by Alvaro Jaspe. This text may be archived and redistributed both in electronic form and in hard copy, provided that the author and journal are properly cited and no fee is charged for access.

\begin{abstract}
This paper will primarily seek to examine the official response of the Spanish Restoration and Primo de Rivera governments to the events in Ireland during the time of the Irish Civil War and Partition, as well as giving some insights on the reaction within Spanish society. The quotation, attributed to US Ambassador Juan Riaño, was in response to the Provisional Government of Ireland's request for official Spanish recognition of Ireland in post war international institutions. The paper will analyse the extremely cautious response of the Spanish authorities to the emergence of the Irish state, as exemplified by Riaño's quote, which, within the echelons of the Spanish diplomatic service, was viewed as the apparent victory of separatism in Ireland. The paper will also touch on the influential role of the Spanish Ambassador in London, Alfonso Merry del Val, and how his pro-British establishment view coloured the efforts of Dublin to establish diplomatic ties with a country it believed to be a natural historical ally. It will chart the difficulties which prevailed in the setting up of limited diplomatic ties in 1924 and the formal establishment of a Spanish consulate in Dublin in 1927 and examine how the links between Republican Ireland and Monarchical Spain developed until 1931.
\end{abstract}

Key Words: Spain, Ireland, Spanish journals (El Debate, El Socialista, La Vanguardia, El Sol, ABC), Merry del Val, independence, diplomacy.

Resumen. Este artículo se propone examinar la respuesta oficial de los gobiernos de la Restauración española y de Primo de Rivera ante los acontecimientos en Irlanda durante la Guerra Civil y partición de la isla, así como ofrecer una perspectiva sobre la reacción en el seno de la sociedad española. La cita, atribuida al embajador de EEUU Juan Riaño, fue en respuesta a la petición del gobierno provisional de Irlanda para que España reconociera oficialmente a Irlanda en las instituciones internacionales de posguerra. El ensayo analizará la respuesta extremadamente cautelosa de las autoridades españolas ante la emergencia del Estado irlandés, tal como evidencia la respuesta de Riaño, que en las esferas del servicio diplomático español se vio como la aparente victoria del separatismo en Irlanda. El ensayo también abordará el influyente papel del embajador español en Londres, Alfonso Merry del Val, y como su visión pro-británica influyó en los esfuerzos de Dublín por establecer lazos diplomáticos con un país al que se consideraba aliado históricamente natural. Se consignaran las dificultades que imperaron en el inicio de lazos diplomáticos restringidos en 1924 y el establecimiento formal de un consulado español en Dublín en 1927 y se examinará la evolución de las relaciones entre la Irlanda republicana y las España monárquica hasta 1931.

Palabras clave. España, Irlanda, periódicos españoles (El Debate, El Socialista, La Vanguardia, El Sol, $A B C$ ), Merry del Val, independencia, diplomacia.

\section{Political background and pubic opinion to the Irish question 1918-1922}

Ireland and the issue of Irish independence post Easter 1916 was one that did not sit comfortably with the main currents of political and ideological opinion in the Spain of the Restoration. Whilst being an obvious 
embarrassment to the British, which gained it certain support among the right leaning parties and cultural and political elites in Spain that had tended to support the cause of the Central Powers during the Great War, the overtly nationalist, anti-establishment, antimonarchical, rebellious movement did little to endear it to this grouping in Spanish political circles, the so-called 'official Spain'. Similarly, among Spanish nationalist, liberal and leftist groups, sympathetic to the Allies in the War and these progressive causes, - the socalled 'real Spain'- the prominence of the Catholic Church and German support, with its overtones of authority and order, made it difficult for them to identify fully with Irish independence. $^{2}$

In the period immediately after 1916 up to the time of the Sinn Fein movement's victory in the November 1918 elections, which was followed by the establishment of an Irish parliament (Dáil) and the declaration of independence in January 1919, voices on both sides of the ideological divide in Spain had tried to find some affinity with the events unfurling in Ireland. Yet the complexity of the Irish issue, together with the political fault lines in Spain, meant that both ideological camps struggled to warm to the Irish issue.

On the right, the openly Germanophile El Debate viewed the declaration of independence favourably, as an example of how the recent victors in the Great War would not be able to, "dictate, at their pleasure, laws to the rest of the world nor impose their will on weaker states." Whilst pondering on why the events in Ireland were receiving so little attention from Spanish officials and other sectors of the press, the editorial believed that Ireland's example would serve as a reminder to those "simplistic souls” (espíritus simplistas), especially politicians and policymakers, that all future foreign policy would be the "exclusive reserve of those nations who have recently triumphed in the War."(El Debate, 13-Jan-19, p.1). But even it felt it necessary to distance itself from Catholic Ireland's triumph, when comment-

1. For more background on the Central Power- Allies split in Spanish society at the time of the Great War see Romero Salvadó (1999)

2. For more background on the ideological split among liberal and progressive groups in Spain see Romero Salvadó (1999) ators at home and abroad made comparisons between the Irish republican cause and Catalan moves for autonomy. The anti-monarchical and revolutionary tone of the Irish movement was too strong even for this sympathetic publication. Two weeks after the above call for more news of events in Ireland, El Debate published the talk given by Felix de Lisnos y Torriga at the Academy of Jurisprudence in Madrid, outlining the notable differences between the Catalan and Irish cases. Whilst Ireland had suffered centuries of British cruelty, it was claimed that Catalonia had benefited as an equal partner with Castile from the creation of the Spanish empire. (El Debate, 28-Jan-19, p.3) Such comparisons, combined with the escalation of the Anglo-Irish or Tan War, meant that the paper did what it had initially accused others of, and dropped references to Ireland until the end of that conflict in 1921. In the same camp was the newspaper $A B C$ which, whilst championing the anti-British uprising during wartime as part of its pro-Central powers stance, quickly distanced itself from the increasingly violent guerrilla war on the island. In a two page article on the 'Irish problem', the paper admitted that it had previously criticized Britain over its treatment of Ireland and the Irish, but that this had been influenced by German efforts to cover up what was really happening there. That, it now concluded, had been an "injustice. All impartial observers have realised that with regard to Ireland Britain is not to blame. Those worthy of censure, are the Irish.” ( $A B C, 25-F e b-19)$. The rejection of their own autonomy bill (Home Rule), and the relative wealth of the island within the British Empire meant the Sinn Fein republicans found little support from this influential quarter in Spain.

What is even more remarkable about the change of opinion over Ireland within $A B C$ and other conservative papers during this period is the fact that the basis of their reports were written by, or at least informed by, ex Daily Mail journalist, Basil Clarke, who between 1919-21 formed part of a covert British propaganda unit that was involved in the manipulation of media and public debate with the purpose of mounting a harmful propaganda war against the republican movement, competing with Sinn Fein's own equivalent in the battle for British and world opinion. The ten man unit, based in Dublin Castle, was 
under the the command of Colonel Charles Foulkes, with Clarke appointed as head of the Department of Publicity in August 1920. He ensured that propaganda was presented as news by manipulating reports coming out of Dublin Castle, the main journalistic source for news. ${ }^{3}$ $A B C$ printed these carefully fabricated reports produced for both external and internal dissemination as factual events in Ireland, and arguably these formed the basis of opinion for events on the island within Spain, and also for Spanish Embassy staff in London, as evidenced by their reports back to Madrid.

On the left of the political spectrum, liberal and nationalist elements also struggled to identify and sympathise with the republican, or rather for many, Catholic struggle in Ireland. The socialist comment on the emergence of the war and subsequent treaty in June 1921 wavered between the right of the small nation to fight off its oppressor, combined with little sympathy for a nationalism heavily influenced by clericalism (El Socialista, 11-Jan-19, p1; 16-Jan-19, p.1). Often the brief accounts of Irish affairs tended to be limited to the endorsement of the British Labour Party's policy on Ireland, and the hope that the labour leaders on the island would now radicalise and become more like their British counterparts. With the truce in June 1921 and the acceptance of the Treaty on 7 January 1922, the socialist essayist Agustín Harmón devoted four articles to 'Lessons from the Irish peace' (Las lecciones de la paz irlandesa). The British could and should have resolved the issue earlier and their agreement to the establishment of the Irish Free State, far from being an example of Britain's generosity, was an example of her giving in, which would have an impact around the world, especially within the British Empire. (El Socialista, 11-Oct-21, p.1) Yet even whilst acknowledging the significance of the first major change to the post-war scene, the Irish case was still regarded as neither revolutionary or radical by the left in Spain. Harmón concluded that the establishment of the 26 County Free State was "an example of the aspirations of an elite to be distinguished from the aspiration of the masses.” (El Socialista, 18-Jan-22, p.1) Hardly a ringing endorsement.

3. For more on the propaganda war at the time of the Anglo-Irish (Tan) War, and the role of Basil Clarke see Brian P. Murphy (2004).
The Republican press in Spain, which had been overwhelmingly pro-British during the war years, did not openly embrace the Irish cause either. The left leaning republican daily, El País, was quite damning in its coverage of the Sinn Fein electoral victory in November 1918. In its analysis of the significance of the results in Ireland, whilst envying the actual electoral process, which would not have been tolerated in Spain because of the "barely functioning Cortes", the Irish cause was not one close to this Spanish centre-left publication. It felt England had proven itself to be respectful of freedom and liberty because, "It has allowed the Irish, advocates of the independence of the island, to fight the election under their own flag." It went on, "This is the only thing that the Irish separatists have achieved. They will have to settle for autonomy, which given their Germanic traits, their treason and their lack of respect for freedom, they do not deserve." As for those in Spain who wished to compare Catalonia with Ireland, the editorial concluded, "they do not know what they are talking about. It is the biggest insult possible to Catalonia"(El País, 2Jan-19, p.1). From the Catalan perspective itself, the syndicalist view was that Irish nationalism was too fundamentally corrupted by religion, whilst the Catalan political elite were terror-stricken by the violence surrounding the Irish question and had no wish to be considered as comparable ( $\mathrm{La}$ Vanguardia, 6-Jun-16, p.6).

Writing in a similar vein regarding the incompatibility of Catalonia and Ireland was the pro-British liberal daily El Sol. In what was the most extensive coverage of the Sinn Fein election campaign and its significance, Manuel Aznar predicted the victory of this "intransigent separatist" line over the nationalist, which in turn would create "a tremendous Irish problem for politicians in London.” (El Sol, 15-Dec-18, p.1) In what proved to be the most prophetic of the columns from any of the Spanish writers on Ireland, Aznar predicted that "absolute independence and recognition at the Versailles Peace Conference would be next on the separatist agenda", with North American backing. In its coverage of the Anglo-Irish war a series of articles appeared from its London correspondent, Ricardo Baeza, in June 1921, just before the truce. On the occasion of the fire in the Customs House in the city, one of the last attacks of the war, he recalled seeing 
the building during a visit in the autumn of 1920. He informed readers in Spain that, "This was no great piece of architecture, but at its feet ran the Liffey, black, thick and bituminous, hellish, resplendent of obsidian...In a sullen looking Dublin, the Customs House was a blessing, a vision of sweetness" (El Sol, 9-Jun-21, p.1). His reports on the negotiations after the truce leading up to the Dáil's acceptance of the Treaty played down the significance of partial, Irish independence and instead lauded British diplomacy and underlined the improved relations with the US, portraying these events as a victory for Britain in the long term. ${ }^{4}$ In one of his last pieces on the divisions caused by the acceptance of the Anglo-Irish Treaty which established the Irish Free State, Baeza felt that "neutral world opinion will certainly side against Mr De Valera's intransigence." Drawing on a conversation with George Bernard Shaw, the article warned against total financial separation from England. Spanish readers were supposed to have very little sympathy for De Valera's rejection of the Treaty which "would remove the moral support which the civilized world has exercised toward the Irish cause" as all were aware that the "English government has made all of the concessions it possibly can" (El Sol, 25-Dec21, p.1).

The very pro-British El Liberal, with no portent of events to come, concluded that after the elections in November 1918 that "the British Empire is more solid than ever" (El Liberal, 29-Dec-18, p.1). Most references made by this title to the Anglo-Irish war tended to focus very much on the British perspective trying to find a peaceful solution to the "rebellion in Ireland"(El Liberal, 7-Dec-19, p.1). Its London correspondent, Rogelio Echarri spent a week in the country in June 1921 on a trip organised by the Dublin Castle press group of Basil Clarke, which included an eventful visit to Sligo and Leitrim and a tour of Longford with a Black and Tan patrol (El Liberal, 1-Jun-21). His report on the 'suicide' of the five Fenians who attacked the Customs House was very much in keeping with the

4. See El Sol, $8^{\text {th }}$ December 1921, p.1 article 'El nacimiento de un nuevo estado'; for similar references to Britain and Ireland see 10-Dec-21, p1; 15-Dec-21, p.1. official reports of events being produced by that office during the war. Yet this paper, along with others such as $A B C$, had difficulty in adhering to the official reports of events being generated by Dublin Castle. References to the "victims of the English terror" began to pervade the paper and the overtly British stance over Ireland disappeared (El Liberal, 22-Jun-21, p.1). Just how much of a change had occurred was apparent in Álvaro de Albornoz's article on Parnell y Cambó, of December 1921. In a debate on Catalonia, the leader of the Lliga had described the Count of Romanones as responding in a "Gladstone manner" to which the then Prime Minister replied that Cambó could be like Parnell, the leader of the Irish nationalist party. In an in depth analysis of the political situation Albornoz was also scathing about this comparison between Catalonia and Ireland, but, in this case, not because the Irish cause was somehow inferior:

In the first instance there is the ethnic, psychological, social and political difference that exists between Ireland and Catalonia. The secular struggle between Ireland and England is not a literary theme, nor merely an issue over tariffs. It's a tragic struggle against a dominating race and oppressive State, the confiscation of land, the violation of religious conscience and the systematic negation of political liberty. Ireland is rebelling against the tyranny of the Viceroys, against the exploitation of the landlords, against monstrous legal inequalities. This is not a debate over foral rights; what is at stake is the sanctity of the human spirit (El Liberal, 13-Dec-21, p.1).

This was the most sympathetic treatment of the Irish cause in the Spanish liberal progressive press, and as a consequence, stands out. The cessation of hostilities between Britain and Ireland in June 1921, the agreed Anglo-Irish Treaty, establishing the Irish Free State, was viewed by all sections of the press in Spain as significant, be it as a gracious concession on the part of the British, or as a victory for Irish separatism. The embarrassment caused to the authorities in London was one that some of the conservative Catholic press tried to capitalise on, as the Irish struggle had now been legitimised. Now Ireland was portrayed by some sections of public opinion as a social Catholic inspired alternative of statedom, reflecting the opinions of Spanish lay organisations such as the Asociación Católica Nacional de Propagan- 
distas. El Debate, often a mouthpiece for the ACNP, sent its leading foreign correspondent, Manuel Graña, to Dublin to report directly on "Ireland's first steps as a free State, a status acquired at great sacrifice and heroism" (El Debate, 3-Jan-22, p.1). Ireland, it was felt, could serve as a third way for new modern states based on Catholic principles between the Capitalist and Communist models. Instead of this, Graña provided readers in Spain with a first hand account of how a divided Dáil and nation slipped into a civil war. ${ }^{5}$ His own deception and disappointment with events in Ireland, whereby defeat had been snatched from the jaws of victory, was one that was shared across the political spectrum in Spain. Thereafter Spanish interest waned after January 1922 as the complexity and violence of the emerging civil war was one that Spanish opinion of all political hues had difficulty in comprehending.

The diplomatic response to Irish independence. The view from London, the Marquis Alfonso Merry del Val. Spanish Ambassador

Officially, the view taken on events from Dublin was significantly coloured by the Spanish Ambassador in London since 1913, Alfonso Merry del Val. Born in England in 1864, he entered the Spanish diplomatic service in 1882, following in his father's footsteps. By the time of his appointment to the Court of St James in 1913, he had seen diplomatic service in Brussels, Rome, Tangier, Vienna and London. Given his background, his connections with the upper echelons of British society, as an invited guest at the Golden Jubilee celebrations of Queen Victoria, this meant that instead of merely sympathising with the British establishment, Merry del Val was, effectively, an intrinsic part of it. ${ }^{6}$ As such, any historical ties between family name and Ireland were of secondary importance to the overall affinity he felt for the British political elite struggling to control events in their Empire, and of his pro-Allied support in the Great War. In his first direct reference to the 'Irish problem' in April 1917 he sent a personal letter to the Spanish Foreign Minister indicating that Britain was far from blameless for the events unfurling across the Irish Sea.

5. For more on Graña's experiences see A. Jaspe "Manuel Graña in Ireland 1922" in Jane Conroy (ed) Papers from the Royal Irish Academy Symposium on Literature and Travel (New York, 2002: 344-354).
He began his handwritten note by declaring "the only weak point in the armoury of the British Empire is currently Ireland.” British public opinion was aware of this, despite "pride in their steely determination to resist the attacks of their enemies and desire to preserve their system of government in widely dispersed lands over the most heterogeneous of races." He did add, however, "There have been few occasions when the problem has been dealt with clearly and honourably in England, perhaps because those Irish nationalists and separatists, who today are demanding freedom, are proving to be insatiable and uncontrollably vague in their very unreasonable demands." Alongside these were ranged the "fanatic and hardline descendents of the old Scottish settlers of Ulster, today's Unionists, who bear a considerable responsibility for the sad divisions which are tearing apart the neighbouring island.” Also to blame, finally, were the English themselves for whom Ireland was by no means a closed chapter but rather "an event in the recent annals of history for which it should be ashamed, albeit not to the same extent as before" (AMAE, Legajo H2509, Expediente 010). He included an article from a recent Sunday Times written by Lord MacDonnell of Swinford, a previous subsecretary of State, which he felt gave a balanced and accurate view of the situation on the island.

His attitude to Irish independence had hardened by the beginning of 1918. As well as informing Madrid of the latest negotiations between the British government and Irish

6. His Excellency Alfonso, Marquis de Merry del Val served as Ambassador to the Court of St. James from 1913 until the advent of the Republic in Spain in 1931. Chamberlain to King Alfonso XIII, his English teacher, he was an extremely influential figure in forging UK-Spanish relations in the first quarter of the twentieth century. On his return to Spain in 1931 he became involved with elements of Acción Española and returned to London in 1936 at the outbreak of the Civil War to form part of the unofficial parallel insurgent delegation, a shadow embassy that operated out of 22 Hans Place headed by Merry del Val and the Duke of Alba which received instructions from Burgos on a daily basis during the war. Ironically, Merry del Val would later travel to Spain with notorious Communist spy Kim Philby during the latter's reports for The Times. For attitudes within the higher echelons of the Spanish diplomatic service overall during this period see Sánchez Sanz (2001). 
representatives regarding a future parliament, Merry del Val informed his superiors that tensions were being raised by a North American of Spanish descent, "Valera", who was irresponsibly taking advantage of a people "traditionally given to revolt" and easily persuaded by rhetoric. He believed De Valera had been fundamentally flawed in distancing his republican party from the Church as "all movements in Ireland are lost if they do not have the support of the clergy, given the centuries old, deep rooted Catholic sentiment of the Irish soul.” As well as documenting the lack of support for revolt among agricultural and industrial interests in Ireland given the benefits and development engendered by the demand from the war, "a situation similar to our Basque provinces”, Merry del Val included a further series of nine press cuttings from differing sources, "If for no other reason, than to comprehend the tolerance of current British Governments whilst their adversaries do no upset public order" (AMAE, Leg.2509. Exp.10.14-Jan-1918).

The Ambassador had not believed Sinn Fein would prosper, let alone form an independent parliament, the Dáil, in the wake of the November 1918 elections. As such, he and other diplomatic colleagues were ill prepared for that new administration's almost first step which was to send Irish representatives to Paris in January 1919 calling for Ireland's admission to the Versailles Conference, as part of its policy of achieving international recognition for independence (Kennedy and Skelly ed. 2000, p.14). So it was that the Merry del Val's colleague, Juan Riaño, received a letter from Patrick McCartan in the name of the provisional government of Ireland asking for Spanish recognition of the Irish right to participate at Versailles. The Spanish diplomatic response was the equivalent of an ostrich. Riaño noted that "given the nature of the request, this department believes it is best to abstain from replying to the referred document” (AMAE, Leg.2509, Exp.010). Although both Riaño and Merry del Val were regarded as being anglophiles within the Spanish ambassadorial clique, with the latter quite critical of Irish republicanism, neither wished to do anything to harm Spain's own aspirations in the post world war order by damaging relations with a US President, Wilson, with Irish roots and dependent on Irish votes, nor alienate Britain by dint of a formal response. Spain wanted to form a part of the new League of Nations and the Irish request for recognition was, at this stage, an unwanted complication in this delicate diplomatic process. ${ }^{7}$ Thus on 9 January 1919 the reply to the Irish request was, "Caution, stay silent" (AMAE, Leg.2509, Exp.10).

Throughout 1919 there were repeated requests made to the Spanish Government and directly to the Embassy in London "from the so called Irish Government delegation." to formally recognise the new Dáil and Irish independence and sovereignty, as Merry del Val noted in June. ${ }^{8}$ In light of the sheer volume of requests and letters, Madrid requested on 20 June for Merry del Val to report "any developments on this matter to this Ministry” (AMAE, Leg H3108, Exp.010). There seems to have been at least a desire on the part of some Spanish foreign ministry officials to explore the possibility of currying favour with President Wilson by acknowledging the Irish request, in the light of reports from the United States regarding the influence of the Irish vote, and as a way of ensuring support for Spanish aspirations in the new world order. According to Ambassador Riaño's account in the spring of 1919, Madrid was aware of how the issue of Irish independence had been at the top of the domestic political agenda in the US. At a recent meeting in Philadelphia, when asked by the Irish Delegation there if he was going to defend the independent status of Ireland at the peace conference, the President had replied that he could not, as he only "represented one nation." Riaño remarked "That answer has not satisfied the Irish and their sympathisers," adding, "this may be another factor which contributes to undermine the elevated pedestal President Wilson had placed himself on" (AMAE, LegH3108, Exp.010, 10-Mar-19).

Back in London, Ambassador Merry del Val was not sympathetic to Wilson's discomfort, playing down the importance of the Irish groups "in a country that exists exclusively at the mercy of electoral opinion" (AMAE

7. For more background on US-Spanish relations at this time see Montero Jiménez (2004).

8. For example see AMAE Leg.H2510 Exp.070. Letter 20-June-1919. Also contacted on 7-June1919 by letter sent on 27-May-1919 signed by Sean T.O'Ceallaigh and G. Gavan Duffy. Also see AMAE, Leg.H2510, Exp.092. Letter addressed to the Minister of Foreign Affairs, Spain. Dated 30Sep-1919. 
Leg.H2520, Exp.070, 11-Jul-19). The Senate vote to formally recognize Irish independence had "caused deep irritation" in British diplomatic circles and was one with which Merry del Val empathised. After yet another formal request to recognize Irish independence on 20 June, Merry del Val reported five days later on the worsening situation in Ireland, predicting a crisis "for the month of September” (AMAE, Leg.2510, Exp.010 26Jun-19). Having a brother who was Papal Nuncio in Rome, he lamented how the clergy in Ireland, despite having seen their authority challenged by the "separatist leaders", was too weak to oppose the revolutionary campaign which gave a "false description of Ireland's ills under English domination”, adding "when it is well known that for at least one generation the last vestiges of injustice have disappeared." As well as decrying De Valera's trip to the US, describing him as "the agitator (...) the self titled President of the Republic", Merry del Val appeared to be having difficulty taking the Irish request for recognition seriously, concluding to the Minister:

There are no shortage of comical elements in all of this Irish movement in a country where imagination, sentiment, sensationalism and talk play such an important role that exaggerates the reality of the situation, even within Ireland itself. For that reason, we should not take too literally all that is read and said about the neighbouring island, whose international pretensions are not shared by the more serious minded of its inhabitants and should be regarded as seditious (AMAE, Leg H2510, Exp.070 , 26-Jun-19).

Two days later, Merry del Val informed Madrid of a "manifesto published by moderate Irishmen" which proposed a peaceful solution by means of a federation with Britain, a story that appeared that day in The Times. By the time of his next report on Ireland on 11 July, Merry del Val was even more pessimistic regarding a "satisfactory conclusion given the nature of the Irish character and more particularly the secular hatred of the protestants of the North against the Catholics in the South.” The only hope of a peaceful resolution lay in the emergence of "a considerable group of men of goodwill on the neighbouring island cogniscent of the impossibility of their country living separately from England, aware that it would be their ruin." This putative group would have its work hampered by a "Catholic clergy guilty of flirting, without any real conviction, with the local patriotism being stirred up, seeing in this the only way of sustaining the enthusiasm of its faithful, guaranteeing its material survival, neglecting it higher evangelical role." Recent events in Tipperary, the police response, were all unfortunate incidents, "hampering the recent conciliation taking place.” De Valera was again described as nothing more than an "agitator" and the nationalist movement itself as "a superficial political manoeuvre" (AMAE, Leg.H2510, Exp.010, 11-Jul-19).

In his subsequent report, regarding political talks on the future of the island, Merry del Val saw a very bleak future as long as the North continued to be led by "that fanatic, Carson" (AMAE, Exp.2510, Exp.070, 26-Jul-19). In this and other reports on Ireland, Merry del Val had attached newspaper reports from The Times, The Daily Telegraph, The Daily Mail and other major British titles, thereby acting as a conduit for the British propaganda war in Ireland being waged by the nascent Department of Publicity in Parkgate Street in Dublin Castle and the Irish Office in London, under Basil Clarke and Colonel Charles Faulkes, designed to undermine the IRA and boost British standing at home and abroad. To what extent, if at all, Merry del Val was aware of Clarke's role, is not certain, but the unchallenged and fulsome nature of the articles being sent to the Minister in Madrid would suggest that Clarke's department had an influence that extended beyond contemporary newspaper reports and future historical accounts, but which actually helped form foreign government policy at that time. The manner in which Clarke published under his own name in $A B C$ would also suggest that some connection with influential Spanish figures, facilitated by the Ambassador, had been achieved. In the concluding remarks of his report on "Irish demands to be considered an independent and sovereign state”, of 26 July 1919, whilst Merry del Val agreed it would be financially difficult given the "Catholics of the South are mainly agrarian and of a less hard working nature than the industrial North,” he stated that some form of Home Rule was inevitable "which the conservative classes here still shy away from." His final comment to the Minister would not have endeared him to Basil Clarke and his department:

In any case, Irish autonomy appears to be inevitable and indispensable. It cannot be delayed for much longer whatever the sense of 
repugnance such a notion may produce to many good Englishmen (AMAE, Leg.H2510,

Exp.070. 26-Jul-19).

The subsequent request from Sean O'Ceallaigh and Garvan Duffy as envoys of the Government elect of the Irish Republic, sent via the London Embassy, on 30 September 1919 still received no official reply. Yet its main points outlining the nullity of the 'Union', the rejection of British rule, the ratification of the 1916 Republic in the November 1918 elections and 1919 National Assembly were highlighted once more. This time slightly more consideration would have been given to them given Merry del Val's renewed stance. ${ }^{9}$

Whilst accepting that some form of independence was likely, he reported on 30 December 1919 that the British parliament's proposal to create two separate parliaments, in the north and south had been rejected by the Irish press and politicians for "not dealing with fundamental political and financial issues." Merry del Val was convinced that the situation in Ireland was deteriorating, "gradually moving toward an open civil war" (AMAE, Leg.H2528, Exp.070, 30-Dec-19). Thereafter reports from London appear to be limited to further press cuttings. The subsequent civil war not only left the Spanish press, but also its diplomatic representatives non-plussed. The divisions within the newly constituted and contested Free State meant that its potential for diplomatic embarrassment were also diminished on the world stage for nations such as Spain, trying to steer a delicate path between the US and Britain.

Normalization and establishment of diplomatic ties between Dublin and Madrid, 1923-31

With the formation of its own Ministry of External Affairs in 1922, albeit still with Dominion status within the British Commonwealth, the establishment of the League of Nations allowed Ireland to establish its own freedom of action on the world arena, in combination with the establishment of bilateral relations with other states. Spain was arguably one of those countries to which the

9. For the letter in full see AMAE, Leg.2510, Exp.092. Document entitled, 'Reivindicaciones de Irlanda a los efectos de ser reconocida como Estado soberano e independiente', 30-Sep-1919. Merry del Val was still very sympathetic to British attempts to quell the IRA revolt and never questioned the British accounts of events.
Irish looked: Spain, through the legitimization provided to Ireland by the League, could now begin to reciprocate. The concept of "small state predicament" meant that in the years after independence, with fewer external interests, the newly formed Irish state was particularly interested in stable international relations and formalising the rule of law in as many aspects of as possible. ${ }^{10}$ The rebellious state sought conformity in its foreign policy. This meant it was now diplomatically acceptable to the Spanish who saw the benefit of a Catholic Irish ally within Europe as a respectable, nonsubversive counter to Britain, especially one that toned down its Anglophobia and tried to portray a modern, independent stance, not solely dependent on opposition to British interests. ${ }^{11}$

The acceptance into the League of Nations in September 1923 was a big step in that process of legitimization and, not surprisingly, the first formal Spanish diplomatic representation was sent to Dublin in January 1924, resulting in the Modus Vivendi Agreement of 14 March 1924 between Spain and Ireland which allowed for "friendly relations and trade" (AGA, AE, Sig.54 LEG.11725). This Spanish-Irish tie was reinforced by events within the League of Nations itself. Although Spain had been unsuccessful in its attempts to obtain a permanent seat on the Council of the League, after the 1925 Locarno Treaty, it did manage to negotiate an expansion of the Council, allowing it to be re-elected to one of the newly created non-permanent positions. Within the Spanish political elite, this was seen as an elevation in diplomatic status. Spain continued to be re-elected via this route to the Council of the League with comfortable margins thanks to the support of the smaller neutral states in Europe, and the Spanish speaking world. (Bowen; 2001) Ireland was one of the nations that voted for the Spanish candidacy, ensuring in turn the stability it sought and the increased profile this brought to her own foreign policy. In this mutually beneficial context, it is not surprising that the diplomatic ties between the Free State and Spain began to take serious roots.

10. See Gerard Keown, 'Taking the World Stage: Creating an Irish Foreign Policy in the 1920's', in Kennedy and Skelly (2000: 27).

11 See Keown 2000: 40-41. 
After trade there followed in 1927 the establishment of a Spanish Dublin Consulate, approved by Royal Decree Number 16 of 15 January 1927, to which Juan B. Arregui del Campo was appointed as Consul. After his arrival in Westmoreland Street on 6 April, he was quickly reminded by his superior Merry del Val that, as well as trade figures, in particularly those comparing Spanish and French wine prices, all information pertaining to the political situation on the island should be sent firstly to him. In addition, reflecting the increasing political sensitivity of the Primo de Rivera regime, he requested that all "information on well known agitators and declared enemies of our state," applying for passports, should be passed on to London so that "appropriate vigilance" could be organised well in advance. Arregui was forced to apologize on 13 June for sending information regarding an assassination attempt on President Cosgrave directly to Madrid, after being forcibly reminded that "news of interest regarding Ireland" should be sent via the London Embassy (AGA, Sig.54/.11725, docs. 20-Apr-27,20-Apr-27, and 25-Apr-27).

Some other Dublin based diplomats, such as the French representative felt that the Free State was "a sort of German province, a bridge head into the Anglo-Saxon world" or that it was still, "a part of Angleterre." ${ }^{2}$ By the beginning of 1928, Merry del Val had come around to the idea that "the neighbouring Ireland is today almost independent from Great Britain.” Rather than Britain or Germany, the Spanish Ambassador identified the US influence as the determining factor on Irish political development. In his report on the recent visit undertaken by President Cosgrave, and the forthcoming visit of "Sr. Valera, separatist and republican leader of the Opposition" to the US he wrote, "we cannot help but note in these trips the beginning of a predisposition of the US in Ireland, due without doubt to Irish immigration caused in times past by British pressure." With regard to Europe, Ireland was the exception to the current US policy of isolation "and would play a more significant part (in Ireland) with the passing of time." Irish political leaders were aware of the huge financial and moral influence of the Irish descendents in the US which Merry del Val concluded would be

12. See Keown 2000: 36. "decisive in the life of the island" (AMAE, LegH2514, Exp.014, dated 7-Jan-28). Merry del Val went on to inform Madrid the following month that Fine Gael and Cosgrave "had administered with great skill and without fear of nationalist interests, without giving into the obstacles and mercenary crimes" the government of the Free State. Similarly, in the North, "the good government and moderation demonstrated by the Administration" had greatly improved "the political state throughout the island and with Great Britain.” Political stability might be achievable in Ireland:

Were it not for the impetuous and ambitious ego of Sr.Valera and his followers, always ready to excite revolutionary passions with cynical, manipulative objectives. All fears regarding the future could be over. Unfortunately it would be premature to formulate such an optimistic outcome (AMAE, LegH2514, Exp.014, 14-Feb28).

It was almost as if Merry del Val, recently bestowed, with the title of Marquis, was doing everything in his power to distance the Spanish monarchy from the Spanish antecedents of the Fianna Fáil leader lest his ideology be associated with Spain; republicanism by the late 1920s was not just something to be feared in Ireland. ${ }^{13}$

As such the new Consul was also asked to be vigilant for any information regarding Spain which appeared and to report anything critical of the Monarchy. To this end, in the first few months in post, Arregui wrote about Dr Walter Starkie's talks at Trinity College of the emergence of a "progressive Spain" as its first professor of Spanish and of an article which appeared in the Irish Times on 21 March on "The Catalan Problem"(AGA, Leg.54/11725, 20-Feb-28, 21-Mar-28). Also noted was the official mark of respect by the flying of flags at half mast on official buildings for the death of Queen Maria Christina, something which had been ordered from the highest office of the Free State (National Archives, Dublin, Dept.of Taoiseach, S66646).

Arregui was replaced early in 1929 by the interim Consul, Ambrose Aliaga Kelly, who in turn was superseded by F. Escudero in March.

13. See article entitled "Decadent?" Time 3-Oct1927 where Merry del Val responded to the "disreputable politician and brilliant novelist" Ibañez's "arrant tissue of airy inventions" made against the Primo de Rivera regime and the monarchy. 
On taking up his position among the correspondence awaiting his attention was a letter from Jack Butler Yeats complaining to the Spanish Consulate that as yet no official invitation had been sent to Irish artists to participate in the Seville and Barcelona world trade fairs. Escudero was quickly involved in a round of public talks to publicize his arrival and to counter reports appearing in the Irish press about unrest in Spain and the rise of republicanism, as well as bemoaning the limited resources available to do so and the lack of space in the consular building (AGA, $54 / 11725$, letters of 15 -Apr-29, articles 23Apr-29).

The press reports regarding the increase in republican sentiment on the Iberian peninsula did not endear the Spanish representative to a meeting with the more out and out republican representatives of the Dáil. On 25 May Escudero informed London that since he had first arrived, "it has been suggested by friends and admirers of De Valera that I should pay him a visit, justified, in their eyes, by his political importance.” Other factors justifying for the meeting were his imminent accession to power and that "in my capacity as a provider of information, no one could provide me with as an insightful view as he." It appears Escudero was being groomed by Maria O'Brien and J.E. Dillon as a potential ally abroad for De Valera's new constitutional role as head of Fianna Fáil. Despite an invitation to the Dáil as a guest of Sean T. Kelly, one of De Valera's aides, Escudero felt he could not accept an invitation from "such a well known agitator." As for a meeting with De Valera, the best Escudero could do was arrange for "a chance meeting", given that protocol would not allow him to meet leaders of the opposition before official government representatives which, in his view, "is clearly wrong and impertinent" (AGA,Sec.AE.Caja 54/11725, letter to Merry del Val 25-May-29).

This illustrates how important both the Fianna Gael government and the new Fianna Fáil opposition regarded the work of forging strong ties with foreign powers. The Irish desire for peace and the maintenance of the status quo to allow for the consolidation of the newly independent state, was one that met a favourable response from a monarchical Spanish regime also looking to at least consolidate its newly limited role in European affairs.

So it was that on 18 June 1929 the Spanish Consular representative, after a delay caused by missing documentation, was able to present his diplomatic credentials to President Cosgrave as Consul General. In the meeting, also attended by the Secretary of Foreign Affairs, Joseph Walshe, Escudero commented that both men were "extremely friendly to me." He went onto add:

During the course of the conversation with Cosgrave, he was extremely interested in asking me about His Majesty the King, as well as recalling the ancient bond of arms between our two nations as well as our shared beliefs, paying particular attention to the continued existence of the Irish College in Salamanca which to this day represents a spiritual link between Spain and Ireland. ${ }^{14}$

Escudero replied:

I informed him that the Spanish people had followed with interest and sympathy the prolonged suffering of Ireland in the fight to protect its faith, today triumphant, and that it is very honoured in offering its hospitality to the Irish seminaries... On behalf of His Excellency the Ambassador of Spain in London, I congratulated the Government of the Free State for the establishment of diplomatic relations with the Holy See (AGA Sec.A.E.Caja 54/11725, 18-Jun-29).

The agreement with the Vatican earlier in 1929 had certainly confirmed the acceptance of Ireland to many in Spain as an acceptable ally, even for those as initially sceptical of Irish independence and of the Irish, such as the proBritish Ambassador Merry del Val. With the presentation of credentials and the exchange of pleasant platitudes, Spanish official attitudes to Ireland had turned full circle, although suspicion still lingered regarding De Valera, something that Escudero's replacement at the end of the summer of 1929, Antonio Suqué, continued to report back to Madrid, via London, until he too was recalled in August 1931 (AGA, Sec.AE Caja54/11726). By that time, Spain herself was a Republic, but already in the intervening period sufficient commonality of interest between Dublin and Madrid in foreign policy, by no means limited to religion, had been consolidated.

14. This comment reflected how leading Free State officials wanted to put forward a foreign policy underpinned by religious values. See Keown 2000: 39. 


\section{Unpublished material}

Archivo General de la Administración, Alcala de Henares. Sección de Asuntos Exteriores.

Archivo del Ministerio de Asuntos Exteriores, Madrid.

National Archive, Dublin. Department of Foreign Affairs.

National Archive, Dublin. Department of Taoiseoch.

\section{Newspaper sources}

$A B C$

El Debate

El Liberal

El País

El Socialista

El Sol

La Vanguardia

\section{Works Cited}

Bowen, Wayne. 2001. “The Foreign Policy of the Spanish Republic”. Journal of Millennial Studies, Winter. Pages?

Bowyer Bell, J. 2002. “The Irish Troubles Since 1916”. Columbia International Affairs Online, Case Study. 128.

Conroy, Jane (ed) 2003. Cross-Cultural Travel. Papers from the Royal Irish Academy International Symposium on Literature and Travel. New Cork: Peter Lang.

Kennedy, Michael,and Morrison Skelly, Joseph (eds) 2000. Irish Foreign Policy 1919-1966: from Independence to Internationalism. Dublín: Four Courts Press.

Lozano Cutanda, Álvaro. 2005. “Algunas gestiones de mediación del Marqués de Villalobar durante la Primera Guerra Mundial”. UNED. Espacio, Tiempo y Forma, Serie Contemporánea. 17. 93-117.

Monterrey, Tomás. 2003. "Los estudios ingleses en España (1900-1950): contexto ideológico-cultural, autores y obras”. Atlantis, 25.2. 71-96.

Montero Jiménez, José Antonio, 2004. “Las relaciones hispano-norteamericanas en los años de la Primera Guerra Mundial”. Cuadernos de Historia Contemporánea, Num.24 23-47.

Murphy, Brian P. 2007. The origins and organization of British propaganda in Ireland 1920 Cork: Aubane.

Romero Salvado, Francisco J. 1999. Spain 1914-1918. Between War and Revolution. London: Routledge. . 2003. “Fatal Neutrality’: Pragmatism or Capitulation? Spain’s Foreign Policy during the Great War”. European History Quarterly 33. 291-324. 893-914.

2003 “The Great War and the crisis of liberalism in Spain, 1916-1917”. The Historical Journal 46.

Sánchez Sánz, Oscar Javier. 2001. “La formación del diplomático 1890-1914: ¿elitismo o profesionalismo?” Cuadernos de Historia Contemporánea, 23. 241-270.

Schulze Schneider, Ingrid. 1998. “1898: Apuntes sobre la diplomacia internacional y la opinión pública”. Historia y Comunicación Social, 3. 223-238. 